\title{
STUDI PERGERAKAN SEDIMEN AKIBAT FLUKTUASI DEBIT PADA SALURAN TERBUKA (UJI LABORATORIUM)
}

\author{
Fauziah Latif ${ }^{(1}$ Muhammad Said $^{(2}$ Dan Astuti Risky Amalia ${ }^{(3}$ \\ 1) Universitas Mhammadiyah Makassar, Indonesia \\ Email:fausiahlatif524@gmail.com \\ ${ }^{2)}$ Universitas Muhammadiyah Makassar, indonesia \\ Email : Saidmuhammad848@yahoo.co.id \\ 3)Universitas Muhammadiyah Makassar, Indonesia \\ Email : Astuti_riskyamalia@yahoo.co.id
}

\begin{abstract}
Abstrak
Penelitian ini bertujuan untuk mengetahui pengaruh pergerakan sedimen (tegangan geser dasar $\left(\tau_{0}\right)$ tegangan geser kritis $\left(\tau_{\mathrm{c}}\right)$, dan kecepatan geser kritis $\left.\left(\mathrm{U}_{1}\right)\right)$, akibat fluktuasi debit. Dan untuk mengetahui pengaruh perubahan dasar saluran (Agradasi dan Degradasi) akibat pergerakan sedimen. Penelitian ini dilakukan dengan mengukur tinggi muka air dan kecepatan aliran pada 10 titik di saluran, pengukuran dilakukan ketika air sudah stabil, pengukuran tinggi gerusan dan pengendapan dilakukan pada waktu saluran dalam kondisi kering. Penelitian ini menghasilkan variasi debit (Q1) : 0,0026 $\mathrm{m}^{3} /$ det, menghasilkan debit aliran $(q)$ di titik 1 sebesar 0,0017 $\mathrm{m} /$ det, tegangan geser $\left(\tau_{\mathrm{d}}\right): 0,870 \mathrm{~kg} / \mathrm{m}^{2}$, tegangan geser kritis $\left(_{\tau_{4}}\right): 1,277 \mathrm{~kg} / \mathrm{m}^{2}$, dan kecepatan geser $\left(u_{*}\right): 0,029 \mathrm{~m} /$ det rata-rata ${ }_{7} \mathrm{O}<_{\pi_{4}} \mathrm{cmaka}$ butiran sedimen tersebut cenderung diam. Pada debit (Q2) : 0,0039 $\mathrm{m}^{3} /$ det, menghasilkan debit aliran $(q)$ di titik 2 sebesar 0,0054 $\mathrm{m} /$ det, tegangan geser $\left(\tau_{\alpha}\right): 1,299 \mathrm{~kg} / \mathrm{m}^{2}$, tegangan geser kritis $\left(\tau_{\tau_{\Sigma}}\right): 1,350 \mathrm{~kg} / \mathrm{m}^{2}$, dan kecepatan geser $\left(u_{*}\right): 0,0361 \mathrm{~m} /$ det menghasilkan ratarata $\tau_{\mathrm{o}}=\tau_{\mathrm{c}}$ dan $\mathrm{\tau} \quad \tau_{\mathrm{o}}>\mathrm{c}$ sehingga butiran sedimen tersebut cenderung mulai bergerak, dan bergerak. Semakin besar debit pengaliran semakin besar pula pergerakan sedimen. kedalaman gerusan yang terjadi sangat dipengaruhi oleh variasi debit, semakin besar debit semakin besar pula gerusan yang terjadi.
\end{abstract}

Kata Kunci: Saluran Terbuka, Debit flow, Angkutan Sedimen,

\begin{abstract}
This research aim to to know influence of movement of sediment ( tension shift, tension shift critically, and speed shift critically), effect of debit fluctuation. and to know change of channel base ( agradasi of degradesi ) effect of movement of sediment, this research is conducted] with measuring is high of face irrigate and speed of stream at 10 channel, measurement conducted by when water have stabilized, altimetry agradasi of degradasi conducted by when channel in a condition run dry. this research yield debit variation of ( Q1) : $0.0026 \mathrm{~m}^{3} / \mathrm{second}$, yielding stream debit in channel 1 equal to $0.0017 \mathrm{~m}^{3} / \mathrm{second}$, tension shift $0.870 \mathrm{~kg} / \mathrm{m}^{2}$, tension shift critical $1.277 \mathrm{~kg} / \mathrm{m}^{2}$ and speed shift $0.029 \mathrm{~m} / \mathrm{second}$. Yielding flattens to < tc hence the sediment item tend to to be kept quiet at debit of Q2 $0.0039 \mathrm{~m}^{3} / \mathrm{second}$ yielding stream debit in channel 2 equal to

$0.0054 \mathrm{~m} / \mathrm{second}$. tension shift $1.299 \mathrm{~kg} / \mathrm{m}^{2}$, tension shift critical $1.350 \mathrm{~kg} / \mathrm{m}^{2}$ and speed shift $0.0361 \mathrm{~m} / \mathrm{second}$, yielding flattens to $=t c$ of to $>$ tc so that item of sediment tend to start to make a move. ever greaterly of ever greater jetting debit also movement of sediment. into gerusan that happened very influenced by debit variation of, ever greater of debit hence ever greater also scour that happened.
\end{abstract}

Keywords: open channel, debit flow, transportation of sediment 


\section{PENDAHULUAN}

Proses sedimentasi meliputi proses erosi, transportasi (angkutan), pengendapan (deposition). Proses tersebut berjalan sangat kompleks, dimulai dari jatuhnya hujan yang menghasilkan energi kinetic yang merupakan awal dari proses erosi. Begitu tanah menjadi partikel halus, lalu menggelinding bersama aliran, sebagian akan tertinggal pada tanah sedangkan sebagian lagi masuk ke dalam sungai terbawa aliran menjadi angkutan sedimen.(Iskandar dan Tony, 2013).

Pengendapan umumnya merupakan akibat adanya erosi dan sebagai perantara utamanya adalah air. Di sungai ataupun saluran - saluran irigasi, jika terjadi pengendapan akan menyebabkan pendangkalan dan hal ini sangat berpengaruh bagi kehidupan manusia. Masalah yang sering dijumpai yaitu terjadinya pengendapan disepanjang saluran bangunan air, yang dapat menimbulkan banjir dan kerusakan bangunan pengaman lainnya. Sedimen berperilaku bergerak, bergeser, dan meloncat disepanjang dasar aliran atau bergerak melayang pada aliran, Tujuan penelitian ini adalah :

1) Untuk mengetahui pengaruh pergerakan sedimen (tegangan geser dasar $\left(\tau_{0}\right)$, tegangan geser kritis $\left(\tau_{c}\right)$
, dan kecepatan geser kritis $\left(U_{*}\right)$, akibat fluktuasi debit.

2) Untuk mengetahui pengaruh perubahan dasar saluran (Agradasi dan Degradasi) akibat pergerakan sedimen.

Adapun manfaat dari penelitian ini adalah :

Untuk mendapatkan pengetahuan dan memberikan informasi tentang angkutan sedimen dasar pada saluran terbuka yang dapat dijadikan sebagai salah satu dasar dalam merancang bangunan - bangunan pengendali sungai maupun saluran saluran irigasi, perbaikan navigasi, perancangan bangunan pelindung pantai, pelabuhan / dermaga dan bangunan bangunan lainnya.

\section{Sedimen}

Sedimen adalah hasil proses erosi, baik berupa erosi permukaan, erosi parit, atau jenis erosi tanah lainnya. Sedimen umumnya mengendap di bagian bawah kaki bukit, di daerah genangan banjir, di saluran air, sungai, dan waduk. Hasil sedimen (sediment yield) adalah besarnya sedimen yang berasal dari erosi yang terjadi di daerah tangkapan air yang diukur pada periode waktu dan tempat tertentu.

Menurut Mardjikoen (1987), angkutan sedimen merupakan perpindahan tempat 
bahan sedimen granular (non kohesif) oleh air yang sedang mengalir searah aliran. Banyaknya angkutan sedimen $\mathrm{T}$ dapat ditentukan dari perpindahan tempat suatu sedimen yang melalui suatu tampang lintang selama periode waktu yang cukup.

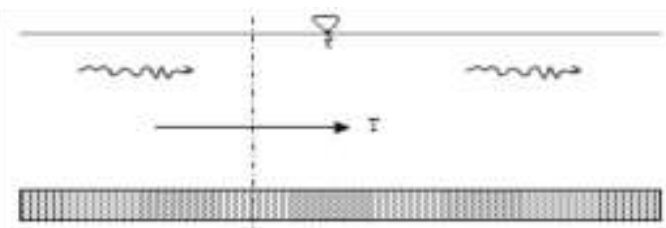

Gambar 1. Tampang panjang saluran dengan dasar granuler.(Mardjikoen, 1987)

Laju sedimen yang terjadi bias dalam kondisi seimbang (equilibrium). Erosi

(erosion), atau pengendapan

(deposition), maka dapat ditentukan kuantitas sedimen yang terangkut daam proses tersebut. Proses sedimentasi di dasar saluran dapat dilihat pada gambar

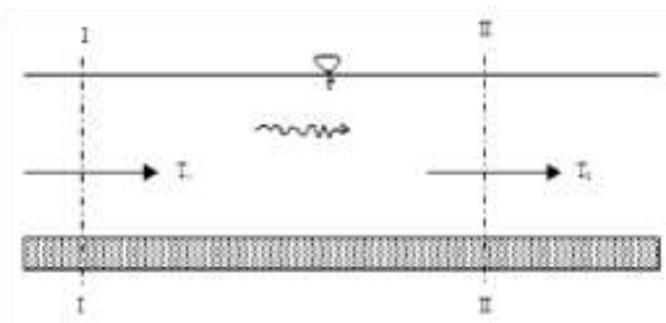

Gambar 2. Angkutan sedimen pada tampang panjang dengan dasar granuler. (Mardjikoen, 1987)

Tabel 1. Proses Sedimen Dasar

\begin{tabular}{ccc}
\hline \multicolumn{3}{c}{ Perbandingan } \\
$\mathbf{T}$ & \multicolumn{2}{c}{ Proses yang terjadi } \\
\cline { 2 - 3 } & Sedimen & Dasar \\
\hline $\mathbf{T}_{\mathbf{1}}=\mathbf{T}_{\mathbf{2}}$ & Seimbang & Stabil \\
\hline
\end{tabular}

\begin{tabular}{ccc}
\hline $\mathbf{T}_{\mathbf{1}}<\mathbf{T}_{\mathbf{2}}$ & Erosi & Degradasi \\
\hline $\mathbf{T}_{\mathbf{1}}>\mathbf{T}_{\mathbf{2}}$ & Pengendapan & Agradasi
\end{tabular}

(Mardjikoen, 1987)

Kecepatan transport merupakan fungsi dari kecepatan aliran sungai dan ukuran partikel sedimen. Partikel sedimen ukuran kecil seperti tanah liat dan debu dapat diangkut aliran air dalam bentuk terlarut (wash load). Sedang partikel yang lebih besar, antara lain, pasir cenderung bergerak dengan cara melompat. Partikel yang lebih besar dari pasir, misalnya kerikil (gravel) bergerak dengan cara merayap atau menggelinding di dasar sungai (bed load). Secara skematis angkutan sedimen dapat digambarkan sebagai berikut :

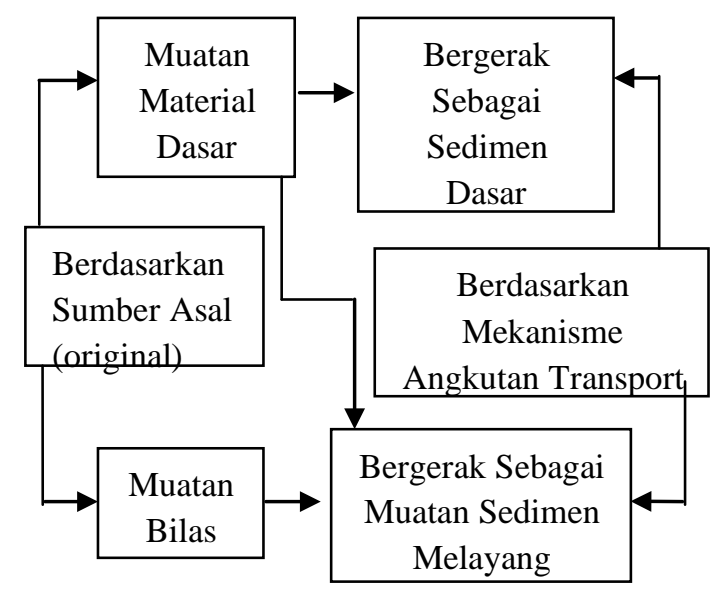

Gambar 3. Bagan mekanisme dan asal bahan sedimen (Mardjikoen, 1987) Tegangan Geser Dasar,

Permulaan gerak butiran sedimen dasar merupakan awal mula angkutan sedimen. Salah satu faktor yang menyebabkan permulaan gerak sedimen adalah 
kecepatan. Kecepatan efektif untuk Ds = diameter butiran sedimen (m) menggerakan butiran dinyatakan dalam Sedangkan tegangan geser yang terjadi rumus berikut :

$\mathrm{U} *=$ (g.h.I) 0,5

dengan: $\mathrm{U} *=$ kecepatan geser $(\mathrm{m} / \mathrm{dt}) \mathrm{g}$ $=$ gravitasi $(\mathrm{m} / \mathrm{dt} 2) \mathrm{h}=$ kedalaman aliran (m)

$\mathrm{I}=$ kemiringan saluran

Kecepatan geser tersebut digunakan untuk menentukan bilangan Reynolds yang terjadi. Rumus bilangan Reynolds adalah sebagai berikut:

$\operatorname{Re}=\frac{u_{* D}}{v}$

dengan: $\mathrm{Re}=$ bilangan Reynolds

$\mathrm{U} *=$ kecepatan $\operatorname{geser}(\mathrm{m} / \mathrm{dt})$

$\mathrm{D}=$ kedalaman aliran $(\mathrm{m})$

$\mathrm{V}=\operatorname{viskositas}(\mathrm{m} 2 / \mathrm{dt})$

$$
\text { Seetelah bilangan }
$$

Reynolds didapatkan, selanjutnya

digunakan untuk menentukan dimensi

tegangan geser $\left(\mathrm{F}^{*}\right)$ dengan menggunakan diagram Shields. Rumus dimensi tegangan geser adalah sebagai berikut :

$\mathrm{F}_{\neq}=\frac{\tau_{c}}{\left(\rho_{s-\rho_{\mathrm{w}}}\right) D_{s}}$

Dengan

$\mathrm{F} *=$ dimensi tegangan geser $\tau_{\mathrm{c}}=$ tegangan geser kritis $(\mathrm{kg} / \mathrm{m} 2)$

$\rho_{s}=$ berat jenis butiran sedimen $(\mathrm{kg} / \mathrm{m} 3)$

$\rho_{\mathrm{w}}=$ berat jenis air $(\mathrm{kg} / \mathrm{m} 3)$

\section{METODE PENELITIAN}

\section{Tempat dan waktu penelitian}

Penelitian dilaksanakan di labotatorium Fakulatas Teknik Sipil Universitas Muhammadiyah Makassar dengan rencana waktu penelitian selama 3 bulan. Model

\section{Saluran}

Model saluran ini terdiri dari 2 bak penampungan yang berguna sebagai sirkulasi air untuk aliran. Bak penampungan terdapat pada awal dan pada akhir saluran, atau hulu dan hilir. Pada bak 
pertama juga terdapat pintu air yang terbuat dari besi las (pintu sorong). Bak awal dengan ukuran 190×150 cm dan bak kedua dengan ukuran $140 \times 240 \mathrm{~cm}$. Saluran terbuka dengan lebar dasar saluran (B): 35 $\mathrm{cm}$, Tinggi saluran $(\mathrm{H}): 35 \mathrm{~cm}$, panjang saluran: $950 \mathrm{~cm}$, dan kemiringan saluran $1: 0,5$

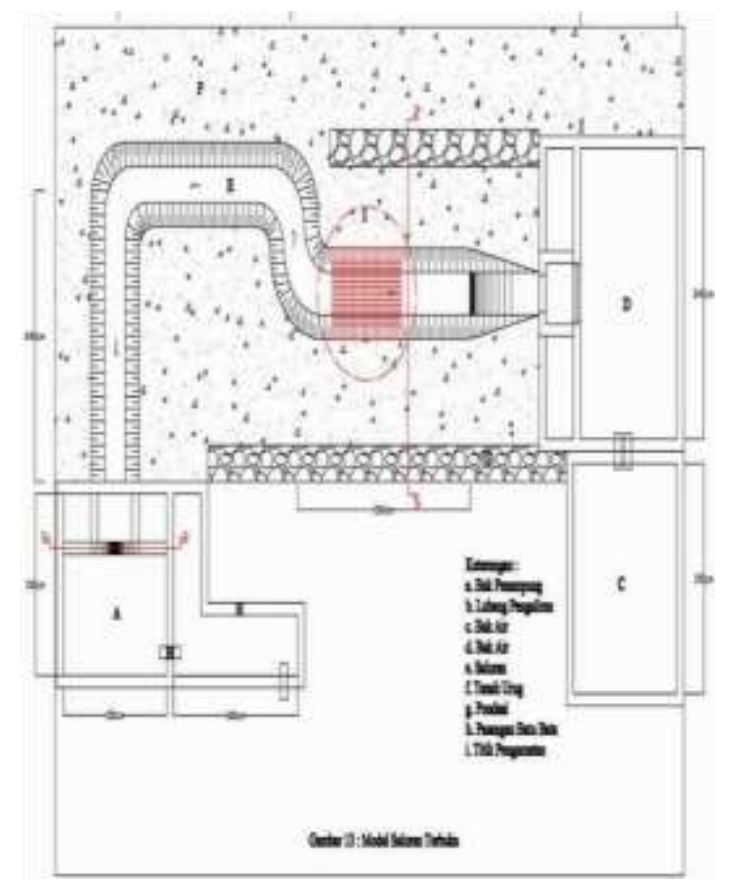

Gambar 4. Denah model penelitian

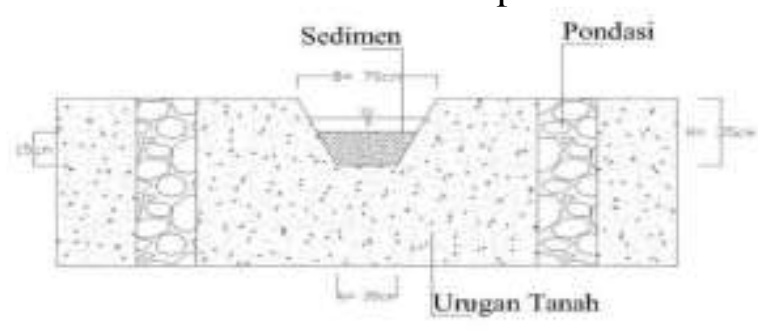

Gambar 14. Potongan A-A

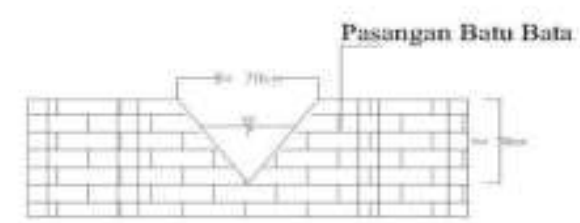

Gambar 15. Potongan B-B
Gambar 5. Potongan Melintang Saluran

Pelaksanaan Studi Model Pelaksanaan simulasi model dilakukan dengan mengukur tinggi muka air dan kecepatan aliran pada 10 titik di saluran pengukuran dilakukan ketika air sudah stabil. Pengukuran tinggi gerusan dan pengendapan dilakukan pada waktu air tidak ada lagi dalam saluran. Dengan butiran yang lolos saringan 8 dan menentukan 3 variasi debit, yang masing-masing terdiri dari 3 variasi waktu.

\section{Bahan dan Alat Penelitian}

Bahan penelitian terdiri dari:

1) Tali yang digunakan sebagai pias atau titik penelitian.

2) Pasir sebagai bahan sediman.

3) Air tanpa kandungan sedimen Alat-alat yang digunakan

1) Saluran terbuka yang dilengkapi dengan pintu air, bak penampungan, bak sirkulasi dan pompa air.

2) Mistar ukur/meteran digunakan untuk mengukur tinggi muka air, tinggi pengendapan dan penggerusan yang terjadi pada dasar saluran.

3) Stop wacth untuk mengukur waktu dalam pengukuran debit aliran. 
4) Flow wacth untuk mengukur kecepatan aliran 5) Kamera untuk dokumentasi.

6) Tabel dan Alat tulis.

\section{Prosedur Penelitian}

1) Membersihkan dan mengeringkan saluran yang akan di gunakan.

2) Melakukan pemadatan tanah pada dasar saluran.

3) Melakukan uji kalibrasi debit pada saluran di laboratorium teknik sungai dan menentukan tinggi bukaan (3 bukaan).

4) Melakukan penyebaran pasir dalam saluran dengan sistem pemadatan setinggi $15 \mathrm{~cm}$ pada saluran.

5) Melakukan pengaliran awal untuk mengetahui layak atau tidaknya saluran yang akan digunakan dalam pengaliran (running awal).

6) Mengalirkan air dengan variasi debit (Q) yang ditentukan dengan membuka pintu saluran setinggi yang telah di tetapkan.

7) Mengamati dan mengambil data kecepatan aliran (v), kedalam aliran (h) di setiap titik dengan waktu $\left(\mathrm{t}_{1}=5\right.$ menit, $\mathrm{t}_{2}=10$ menit dan $\mathrm{t}_{3}=15$ menit).
8) Mematikan pompa agar aliran di saluran berhenti untuk melakukan pengamatan terhadap keadaan dasar saluran.

9) Setelah selesai pengambilan data percobaan pertama, ulangi prosedur sebanyak 2 kali dengan pola yang sama dan bukaan pintu yang telah di tentukan.

\section{Bagan alur penelitian}

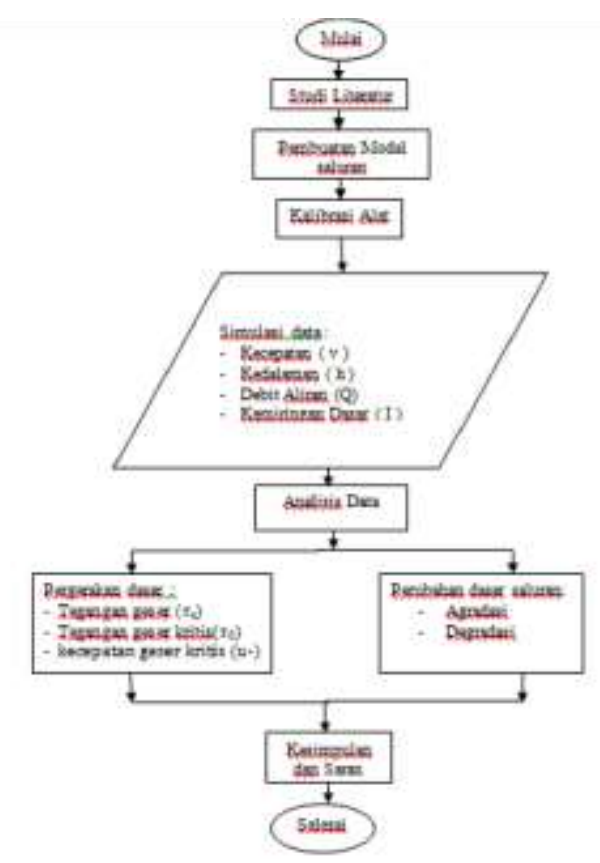

Gambar 6. Gambar Flow chart penelitian

\section{HASIL DAN PEMBAHASAN}

\section{Hasil Penelitian}

Hasil penelitian dari seluruh kegiatan eksperimental ini disajikan halhal yang berkaitan dengan pelaksanaan penelitian meliputi : Pengujian bahan sampel penelitian, pengambilan data kecepatan dan ketinggian air. 
Tabel 2. Hasil Pemeriksaan dan pengambilan data.

\begin{tabular}{|c|c|c|c|c|c|c|c|c|}
\hline \multirow{3}{*}{ Letak } & \multirow{2}{*}{} & \multirow{2}{*}{$\rho$} & \multicolumn{2}{|c|}{ Q } & \multicolumn{2}{|c|}{$\mathrm{Q}$} & \multicolumn{2}{|c|}{$Q$} \\
\hline & & & $\mathrm{h}$ & $\mathrm{V}$ & $\mathrm{h}$ & $\mathrm{V}$ & $\mathrm{b}$ & $\mathrm{V}$ \\
\hline & r & $\mathrm{kg} /$ & (n) & $(\mathrm{m} / \mathrm{d}$ & (n) & $(\mathrm{m} / \mathrm{d}$ & (n) & $(\mathrm{m} / \mathrm{d}$ \\
\hline 1 & \multirow{10}{*}{0.002} & \multirow{10}{*}{25} & 0.0 & 0.1 & 0.0 & 0.2 & 0.0 & 0.6 \\
\hline 2 & & & 0.0 & 0.1 & 0.0 & 0.2 & 0.0 & 0.6 \\
\hline 3 & & & 0.0 & 0.1 & 0.0 & 0.2 & 0.0 & 0.6 \\
\hline 4 & & & 0.0 & 0.1 & 0.0 & 0.3 & 0.0 & 0.6 \\
\hline 5 & & & 0.0 & 0.1 & 0.0 & 0.3 & 0.0 & 0.6 \\
\hline 6 & & & 0.0 & 0.1 & 0.0 & 0.3 & 0.0 & 0.7 \\
\hline 7 & & & 0.0 & 0.1 & 0.0 & 0.3 & 0.0 & 0.7 \\
\hline 8 & & & 0.0 & 0.2 & 0.0 & 0.3 & 0.0 & 0.8 \\
\hline 9 & & & 0.0 & 0.2 & 0.0 & 0.3 & 0.0 & 0.8 \\
\hline 1 & & & 0.0 & 0.2 & 0.0 & 0.4 & 0.0 & 0.8 \\
\hline
\end{tabular}

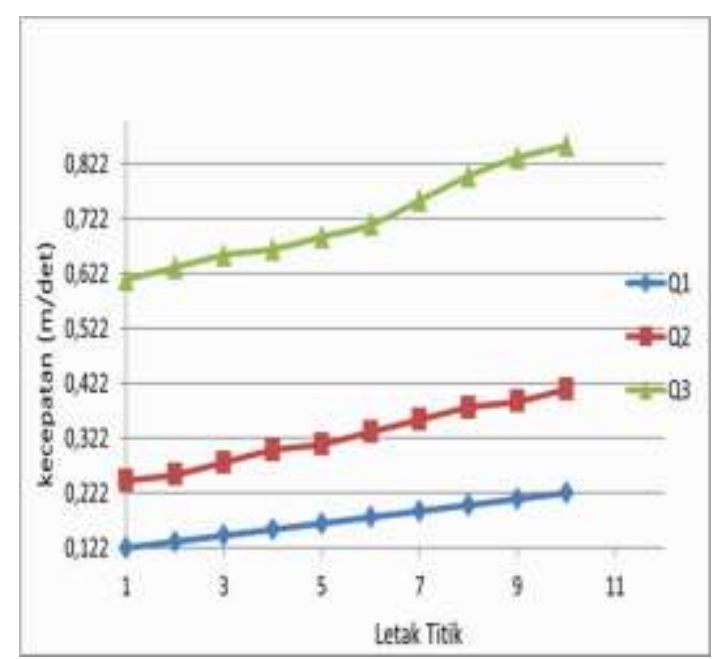

Gambar 7 Pengaruh Letak titik terhadap kecepatan aliran untuk debit (Q1) 0,0026 $\mathrm{m}^{3} /$ det, debit (Q2) $0,0039 \mathrm{~m}^{3} / \mathrm{det}$ dan debit (Q3) $0,0071 \mathrm{~m}^{3} /$ det.

\section{Analisis}

\section{Pengaruh Pergerakan Sedimen di}

\section{Dasar Saluran Akibat Fluktuasi Debit}

Tabel 3. Data debit penampang dengan tegangan geser $(\tau)$ tegangan geser kritis $(\tau$

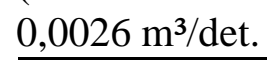
untuk debit (Q1)

\begin{tabular}{|c|c|c|c|c|}
\hline \multirow{3}{*}{ No Patok } & \multicolumn{4}{|c|}{ Q1 } \\
\hline & $\mathrm{q}$ & 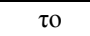 & $\tau$ & $u_{*}$ \\
\hline & $\overline{(\mathrm{m} / \mathrm{det})}$ & $\mathrm{kg} / \mathrm{m}^{2}$ & $\mathrm{~kg} / \mathrm{m}^{2}$ & $\mathrm{~m} / \mathrm{det}$ \\
\hline 1 & 0.0017 & 0.8705 & 1.2770 & 0.0295 \\
\hline 2 & 0.0019 & 0.8825 & 1.2406 & 0.0297 \\
\hline 3 & 0.0021 & 0.9112 & 1.2041 & 0.0302 \\
\hline 4 & 0.0024 & 0.9472 & 1.0946 & 0.0308 \\
\hline 5 & 0.0026 & 0.9760 & 0.9778 & 0.0312 \\
\hline
\end{tabular}

\begin{tabular}{ccccc}
\hline 6 & 0.0029 & 0.9928 & 0.9924 & 0.0315 \\
\hline 7 & 0.0031 & 1.0000 & 0.9122 & 0.0316 \\
\hline 8 & 0.0033 & 1.0072 & 0.8757 & 0.0317 \\
\hline 9 & 0.0035 & 1.0287 & 0.8027 & 0.0321 \\
\hline 10 & 0.0038 & 1.0671 & 0.7297 & 0.0327 \\
\hline Sumber : Hasil Perhitungan & & &
\end{tabular}

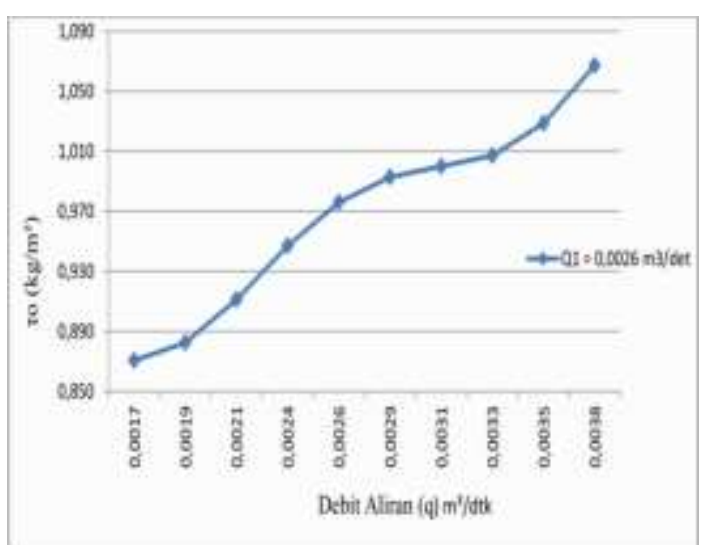

Gambar 8. Pengaruh Debit Aliran (q) Terhadap Tegangan Geser Dasar $(\tau)$

Pada gambar 8. Dengan variasi debit (Q1) 0,0026 m³/det, debit aliran suatu penampang di dasar saluran (q) : $0,0017 \mathrm{~m} /$ det, tegangan geser dasar $(\tau)$ : $0,870 \mathrm{~kg} / \mathrm{m}^{2}$. Semakin besar debit aliran pada suatu penampang dasar saluran maka tegangan geser semakin besar.

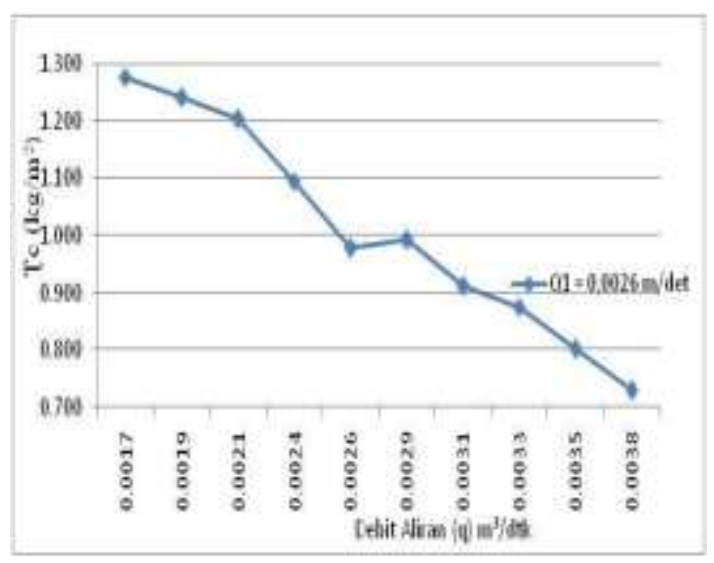

Gambar 9. Pengaruh Debit Aliran (q) Terhadap Tegangan Geser kritis $(\tau)$ Untuk debit (Q1) 0,0026 m²/det.

Pada gambar 9. Dengan variasi debit (Q1) 0,0026 $\mathrm{m}^{3} /$ det, debit aliran 
suatu penampang di dasar saluran (q) : $0,0017 \mathrm{~m} / \mathrm{det}$, tegangan geser kritis $(\tau)$ : $1,277 \mathrm{~kg} / \mathrm{m}^{2}$. Semakin besar debit aliran pada suatu penampang dasar saluran maka tegangan geser kritis semakin kecil.

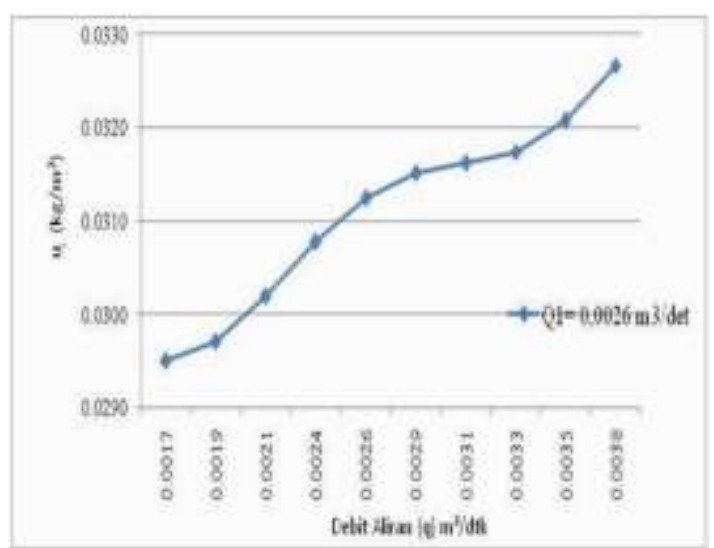

Gambar 10. Pengaruh Debit Aliran (q) Terhadap Kecepatan Geser kritis (u*) Untuk debit (Q1) 0,0026 m³/det.

Pada gambar 10. Dengan variasi debit (Q1) 0,0026 m³/det, debit aliran suatu penampang di dasar saluran (q) : $0,0017 \mathrm{~m} /$ det, kecepatan geser $\left(u_{*}\right): 0,029$ m/det. Semakin besar debit aliran pada suatu penampang dasar saluran maka kecepatan geser semakin besar.

Tabel 9. Data debit penampang dengan tegangan geser $(\tau)$ tegangan geser kritis $(\tau$ ) untuk debit (Q2) $0,0039 \mathrm{~m}^{3} / \mathrm{det}$

\begin{tabular}{cccc}
\hline \multicolumn{4}{c}{$\mathrm{Q} 2$} \\
\hline $\mathrm{q}$ & $\tau \mathrm{O}$ & $\tau$ & $\mathrm{u}_{\star}$ \\
\hline$(\mathrm{m} / \mathrm{det})$ & $\mathrm{kg} / \mathrm{m}^{2}$ & $\mathrm{~kg} / \mathrm{m}^{2}$ & $\mathrm{~m} / \mathrm{det}$ \\
\hline 0.0050 & 1.2590 & 1.4230 & 0.0355 \\
\hline 0.0054 & 1.2997 & 1.3500 & 0.0361 \\
\hline 0.0060 & 1.3333 & 1.3135 & 0.0365 \\
\hline 0.0067 & 1.3693 & 1.2770 & 0.0370 \\
\hline 0.0069 & 1.3717 & 1.2406 & 0.0370 \\
\hline 0.0075 & 1.3836 & 1.2041 & 0.0372 \\
\hline 0.0082 & 1.4220 & 1.1676 & 0.0377 \\
\hline 0.0089 & 1.4532 & 1.1311 & 0.0381 \\
\hline 0.0093 & 1.4700 & 1.0946 & 0.0383 \\
\hline
\end{tabular}

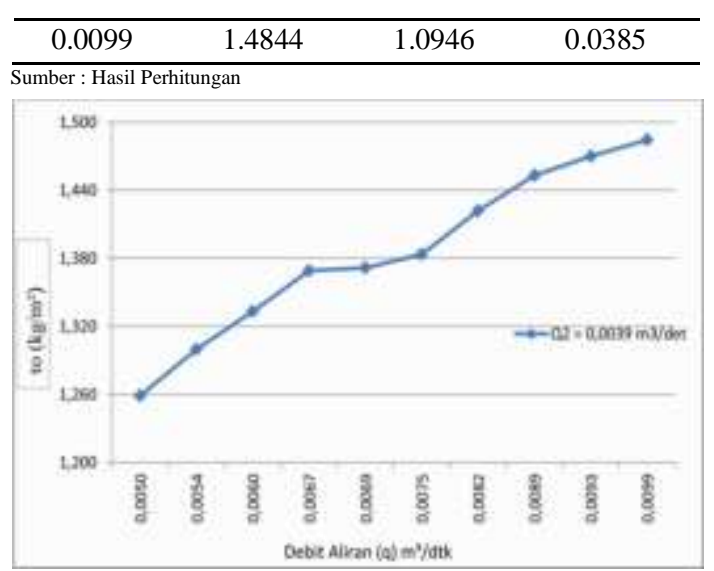

Gambar 11. Pengaruh Debit Aliran (q) Terhadap Tegangan Geser Dasar $(\tau)$ Untuk debit (Q2) 0,0039 m³/det.

Pada gambar 11. Dengan variasi debit (Q2) $0,0039 \mathrm{~m}^{3} / \mathrm{det}$, debit aliran suatu penampang di dasar saluran (q) : 0,0050 $\mathrm{m} / \mathrm{det}$, tegangan geser dasar $(\tau): 1,259 \mathrm{~kg} / \mathrm{m}^{2}$. Semakin besar debit aliran pada suatu penampang dasar saluran maka tegangan geser semakin besar.

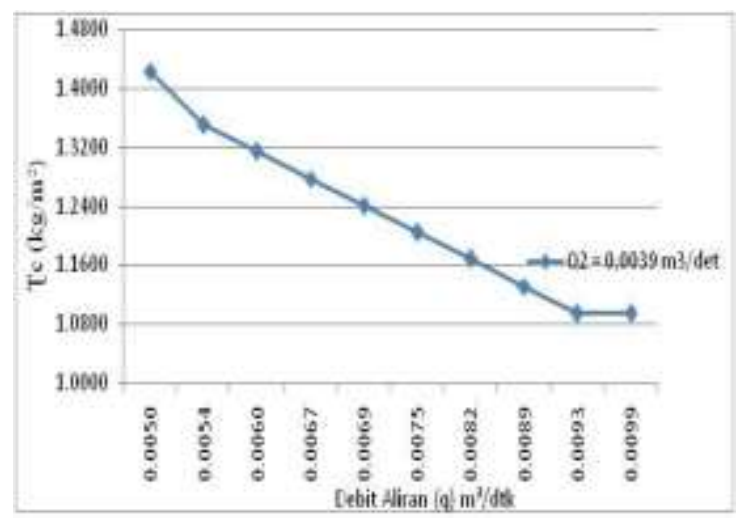

Gambar 12. Pengaruh Debit Aliran (q) Terhadap Tegangan Geser Kritis $(\tau)$ Untuk debit (Q2) 0,0039 m³/det. ada gambar 12 . Dengan variasi debit (Q2) $0,0039 \mathrm{~m}^{3} / \mathrm{det}$, debit aliran suatu penampang di dasar saluran (q) : 0,0050 m/det, tegangan geser kritis $(\tau): 1,423 \mathrm{~kg} / \mathrm{m}^{2}$. Semakin besar debit aliran pada suatu penampang dasar saluran maka tegangan geser kritis semakin kecil. kecepatan geser semakin besar. 
Tabel 10. Data debit penampang dengan tegangan geser $(\tau)$ tegangan geser kritis $(\tau$ ) untuk debit (Q3) $0,0071 \mathrm{~m}^{3} / \mathrm{det}$

\begin{tabular}{cccc}
\hline \multicolumn{5}{c}{ Q3 } \\
\hline $\mathrm{q}$ & $\tau \mathrm{O}$ & $\tau$ & $\mathrm{u}_{*}$ \\
\hline$(\mathrm{m} / \mathrm{det})$ & $\mathrm{kg} / \mathrm{m}^{2}$ & $\mathrm{~kg} / \mathrm{m}^{2}$ & $\mathrm{~m} / \mathrm{det}$ \\
\hline 0.0160 & 1.6187 & 1.3865 & 0.0402 \\
\hline 0.0169 & 1.6426 & 1.3500 & 0.0405 \\
\hline 0.0177 & 1.6666 & 1.2770 & 0.0408 \\
\hline 0.0182 & 1.6858 & 1.2406 & 0.0411 \\
\hline 0.0188 & 1.6858 & 1.2406 & 0.0411 \\
\hline 0.0196 & 1.6978 & 1.2406 & 0.0412 \\
\hline 0.0209 & 1.7026 & 1.2406 & 0.0413 \\
\hline 0.0224 & 1.7266 & 1.1676 & 0.0416 \\
\hline 0.0235 & 1.7386 & 1.1311 & 0.0417 \\
\hline 0.0245 & 1.7649 & 1.1311 & 0.0420 \\
\hline Sumber : Hasil Perhitungan & &
\end{tabular}

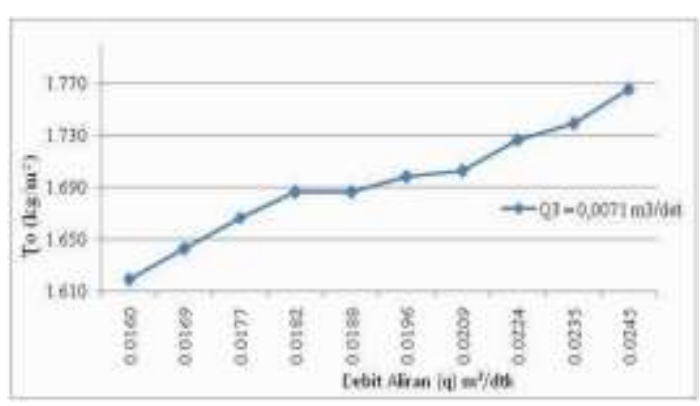

Gambar 13 Pengaruh (q) Terhadap $(\tau$ ) Untuk debit (Q3) 0,0071 m²/det. maka tegangan geser kritis semakin kecil

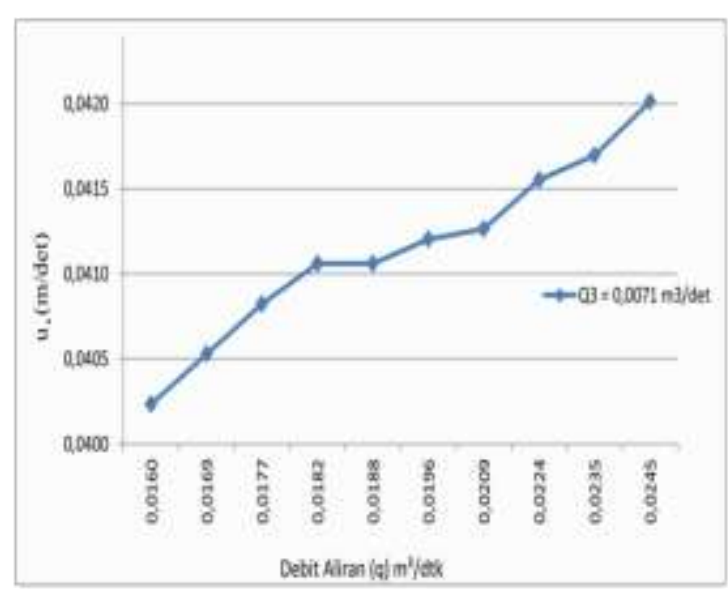

Gambar 16. Pengaruh Debit Aliran (q) Terhadap Kecepatan Geser kritis $\left(\mathrm{u}_{*}\right)$ Untuk debit (Q3) 0,0071 m³/det.

Pada gambar 16. Dengan variasi Untuk debit (Q3) 0,0071 m³/det. debit (Q3) 0,0071 m³/det, debit aliran suatu penampang di dasar saluran (q) : 0,016 $\mathrm{m} /$ det, kecepatan geser $\left(u_{1}\right): 0,040 \mathrm{~m} /$ det . Semakin besar debit aliran pada suatu penampang dasar saluran maka kecepatan geser semakin besar.

\section{Pengamatan Perubahan Dasar Saluran}

\section{(Agradasi dan Degradasi) Akibat \\ Perubahan Debit}

Penelitian ini dilakukan dengan menggunakan butiran sedimen dan variasi debit $\mathrm{Q}_{1}, \mathrm{Q}_{2}$ dan $\mathrm{Q}_{3}$. Cara mengamati gerusan dan pengendapan yaitu dengan mencatat kedalaman gerusan dan tinggi pengendapan pada setiap setelah pengaliran dengan variasi debit. Bentuk gerusan yang terjadi pada tiap percobaan berdasarkan dan penggunaan surfer 8.0 adalah sebagai berikut :
a. Kedalaman
Gerusan dan
Pengendapan untuk debit (Q1) : $0,0026 \mathrm{~m}^{3} / \mathrm{dtk}$, durasi 30 menit.

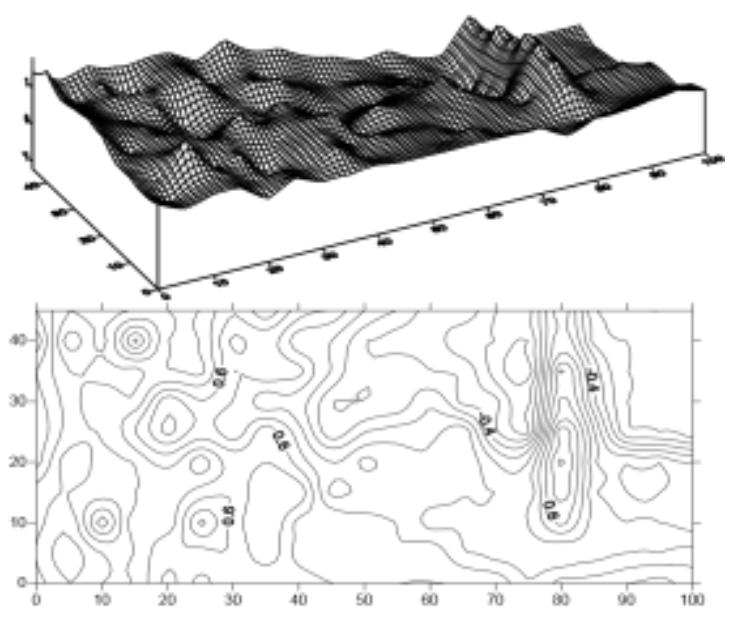

Gambar 17 : Perubahan dasar saluran hasil Grafik 
setelah percobaan pertama .

b. Kedalaman Gerusan dan

Pengendapan untuk debit (Q2) : $0,0039 \mathrm{~m}^{3} / \mathrm{dtk}$, durasi 30 menit.

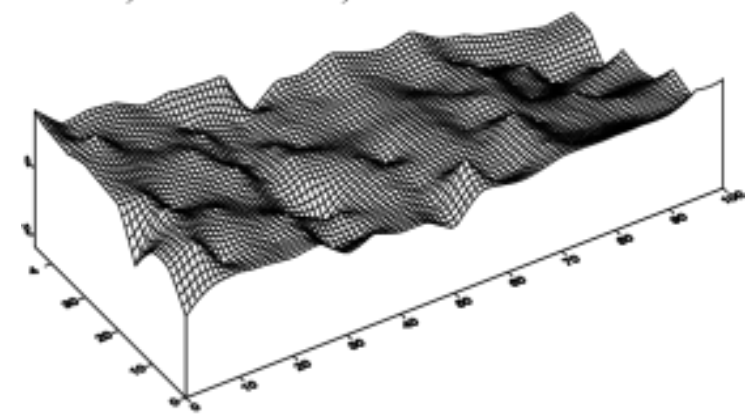

Gambar 18 : Perubahan dasar saluran setelah percobaan kedua

c. Kedalaman Gerusan dan

Pengendapan untuk debit (Q3) : $0,0071 \mathrm{~m}^{3} / \mathrm{dtk}$, durasi 30 menit.

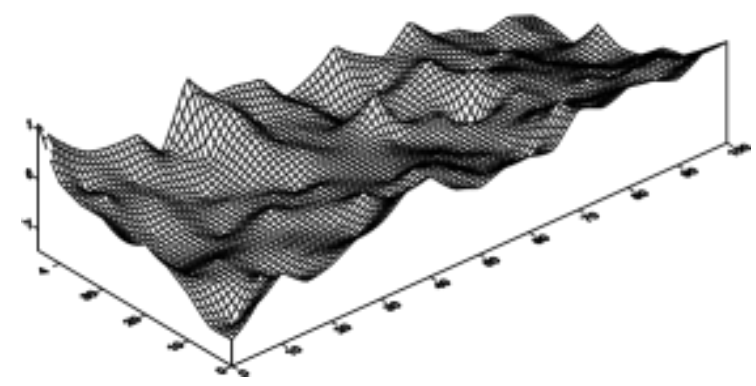

Gambar 19 : Perubahan dasar saluran setelah percobaan ketiga.

Kedalaman gerusan dan pengendapan untuk (Q1) : 0,0026 m²/dtk durasi 30 menit yaitu pada titik 1 kedalaman gerusan mencapai $1.8 \mathrm{~cm}$, dan pengendapan tidak terjadi, untuk titik 5 kedalaman gerusan mencapai $0.6 \mathrm{~cm}$, dan pengendapan mencapai $0.4 \mathrm{~cm}$. Kemudian pada titik 10 kedalaman gerusan mencapai $0.5 \mathrm{~cm}$, dan pengendapan mencapai $1.2 \mathrm{~cm}$.
Kedalaman gerusan dan pengendapan untuk Q2 : $0,0039 \mathrm{~m}^{3} / \mathrm{dtk}$ durasi 30 menit yaitu pada titik 1 kedalaman gerusan mencapai $1.7 \mathrm{~cm}$, dan pengendapan tidak terjadi, untuk titik 5 kedalaman gerusan tidak terjadi, dan pengendapan mencapai $0.5 \mathrm{~cm}$. Kemudian pada titik 10 kedalaman gerusan mencapai $0.9 \mathrm{~cm}$, dan

pengendapan mencapai $2.3 \mathrm{~cm}$ Kedalaman gerusan dan pengendapan untuk Q3 : $0,0071 \mathrm{~m}^{3} / \mathrm{dtk}$ durasi 30 menit yaitu pada titik 1 kedalaman gerusan mencapai 1.1 $\mathrm{cm}$, dan pengendapan mencapai $0.9 \mathrm{~cm}$, untuk titik 5 kedalaman gerusan tidak terjadi, dan pengendapan mencapai 0.7 $\mathrm{cm}$. Kemudian pada titik 10 kedalaman gerusan mencapai $0.6 \mathrm{~cm}$, dan pengendapan mencapai $1.3 \mathrm{~cm}$. kedalaman gerusan yang terjadi sangat dipengaruhi oleh variasi debit, semakin besar debit semakin besar pula gerusan yang terjadi.

\section{Penutup}

\section{Kesimpulan}

1) debit pertama (Q1) $0,0026 \mathrm{~m}^{3} / \mathrm{det}$, menghasilkan rata-rata $\tau \mathrm{o}<\tau \mathrm{c}$ maka butiran sedimen tersebut cenderung diam, pada debit kedua (Q2) 0,0039 $\mathrm{m}^{3} / \mathrm{det}$ menghasilkan rata-rata $\tau \mathrm{o}=\tau \mathrm{c}$ dan $\tau \quad \tau \mathrm{o}>\mathrm{c}$ sehingga butiran sedimen tersebut cenderung mulai bergerak, dan bergerak. debit ketiga (Q3) $\quad 0,0071 \mathrm{~m}^{3} / \mathrm{det}$ menghasilkan rata- rata $\tau \mathrm{o}>\tau \mathrm{c}$ maka butiran sedimen di katakan bergerak. 
2) kedalaman gerusan yang terjadi sangat dipengaruhi oleh variasi debit, semakin besar debit semakin besar pula gerusan yang terjadi.

\section{Saran}

Dari pengamatan di dalam penelitian ini penulis memberikan saran - saran untuk penelitian lebih lanjut, yaitu :

1) Untuk penelitian selanjutnya titik pengambilan data (pias) harus lebih rapat dan lebih banyak agar data yang diperoleh lebih jelas dan akurat.

2) Untuk penelitian selanjutnya dilakukan pengamatan dengan sedimen yang lebih bervariasi dan spesifik.

\section{DAFTAR PUSTAKA}

Ahmad Nasirul Umam, 2015. Tugas Ilmiah Sedimentasi (Proses

Sedimentasi)

Asdak,C. 2014.Hidrologi Dan

Pengeloaan Daerah Aliarn Sungai. Gajah Mada University Press, Yogyakarta.

Harianja dan N.A.P., 2011. Pengaruh Perubahan Debit Terhadap Pergerakan Sedimen, Jurnal Teknik Sipil Universitas Kristen Immanuel Yogyakarta.

Ikhsan, Cahyono 2007. Pengaruh Variasi Debit Air Terhadap Laju Bed Load Pada Saluran Terbuka Dengan Pola Aliran Steady Flow, Jurnal Teknik Sipil Fakultas Teknik UNS Surakarta.
Iskandar dan tony, 2013. Studi Sedimentasi Di Muara Sungai Angsa Kecamatan Angsana Kabupaten Tanah Bumbu Kalimantan Selatan, Jurnal Pertania Universitas Achmad Yani Banjar Baru.

Karim, T Nenny. Bahan Kuliah Angkutan Sedimen, Teknik Sipil Unismuh Makassar, 2010.

Mardijikoen, P., 1987. Angkutan Sedimen. Diktat, Pusat Antar Universitas (PAU) Ilmu Teknik, UGM, Yogyakarta

Oliviana Mokonio. Dkk, 2013. Analisis Sedimentasi di Muara Sungai Saluangko Desa Tounelet Kec.

Kakas Kab. Minahasa (http://google,

Rusman Yamsir. 2015. Analisis Pergerakan Sedimen Pada Saluran Dengan Beberapa Variasi Kemiringan, Tugas Akhir Teknik Sipil Universitas Hasanuddin.

Soewarno, 1991. Pengukuran dan pengolahan data aliran sungai, Bandung

Sosrodarsono, suyono, Dkk, 2008, perbaikan dan pengaturan sungai,paradnya paramita,Jakarta

Suripin, 2002. Dalam buku Tata Ruang Air Oleh Restam Sjarief 